University of California

Division of Agriculture and Natural Resources

http://anrcatalog.ucdavis.edu

\title{
Biology and Management of Horseweed and Hairy Fleabane in California
}

\begin{abstract}
ANIL SHRESTHA, Department of Plant Science, California State University, Fresno; KURT HEMBREE, University of California Cooperative Extension Farm Advisor, Fresno County; and STEVEN WRIGHT, University of California Cooperative Extension Farm Advisor, Tulare and Kings
\end{abstract} Counties

In recent years, increasing populations of horseweed, or mare's tail, (Conyza canadensis) and hairy, or flax-leaved, fleabane (Conyza bonariensis) have been observed in vineyards, orchards, canal banks, and roadsides in California, especially in the Central Valley. Numerous growers, pest control consultants, and managers have complained that the recommended rates of some postemergent herbicides, such as glyphosate, are no longer effective on these weeds. Since glyphosate-resistant biotypes of these species have now been confirmed (Shrestha et al., 2007), alternative integrated techniques need to be employed to effectively manage resistant and nonresistant biotype populations and to prevent the further development of herbicide resistance. A basic understanding of the biology of these weeds is essential to develop an integrated management approach.

\section{Biology of Horseweed and Hairy Fleabane}

Horseweed and hairy fleabane are summer annuals belonging to the Asteraceae (sunflower) family. The temperature and light requirements for germination, soil type preference, and depth of soil emergence of these two species are fairly similar. The optimal temperature for germination of both species ranges from $65^{\circ} \mathrm{F}$ to $75^{\circ} \mathrm{F}$, and they can germinate under moderate $(0.4 \mathrm{MPa})$ water stress. However, hairy fleabane can germinate at lower temperatures than

Figure 1. Observed life cycle of horseweed and hairy fleabane in central California

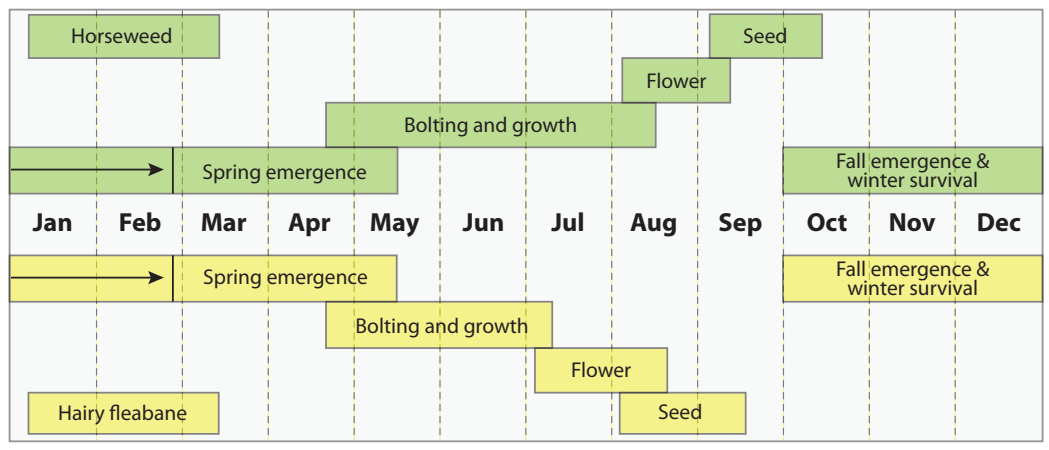

horseweed (Karlsson and Milberg 2007). Some germination of hairy fleabane has been recorded at temperatures as low as $39.5^{\circ} \mathrm{F}$ (Wu et al. 2007). Although both these species can germinate under complete darkness, greater germination occurs under light (Nandula et al. 2006; Vidal et al. 2007). Nanudula et al. (2006) found greatest germination of horseweed under a 13-hour day length. Based on these characteristics, conditions are ideal for horseweed and hairy fleabane germination in mid to late fall (after the first rain or irrigation) and late winter in the Central Valley. Therefore, we often see seedlings emerge multiple times during the year in the Central Valley (fig. 1). Under some conditions, horseweed seeds can germinate year-round (Buhler and Owen 1997). 
Seedlings that germinate and emerge in late fall can overwinter as a rosette and then bolt (elongation of mainstem) in spring. Emergence of these two species is greater and more rapid in coarser than in finer soils (Nandula et al. 2006; Vidal et al. 2007), and germination is greater in soils with a neutral to alkaline $\mathrm{pH}$ range than in acidic soils (Nandula et al. 2006). However, horseweed has been observed in great numbers in the acidic to neutral soils of the southeast Central Valley. Seedling emergence is primarily from the soil surface, and no seedlings emerge from depths greater than 0.2 inch (Nandula et al. 2006; Vidal et al. 2007).

The seeds (fig. 2) and seedlings (fig. 3) of these two species look very similar and are very difficult to distinguish. The characteristic features, at the seedling stage, that may help in distinguishing the two are that the leaves of horseweed are dull green, oval, and have fine, short hairs, whereas the leaves of hairy fleabane are gray-green, narrower, and more crinkled (see fig. 3). Seedlings of these two species can also be confused with common winter annual weeds such as common chickweed (Stellaria media) and shepherd's-purse (Capsella bursa-pastoris).

Horseweed and hairy fleabane plants are difficult to distinguish from each other until about the 12-leaf stage. Once the plants bolt (usually in late April to late May) it is easy to differentiate the two species. Horseweed bolts, sending up a single, or primary, vegetative stem that is erect with dark green leaves that are up to 4 inches long and are crowded together with an alternate arrangement on the stem (fig. 4). The stem is smooth or covered with shaggy hairs. Hairy fleabane, unlike

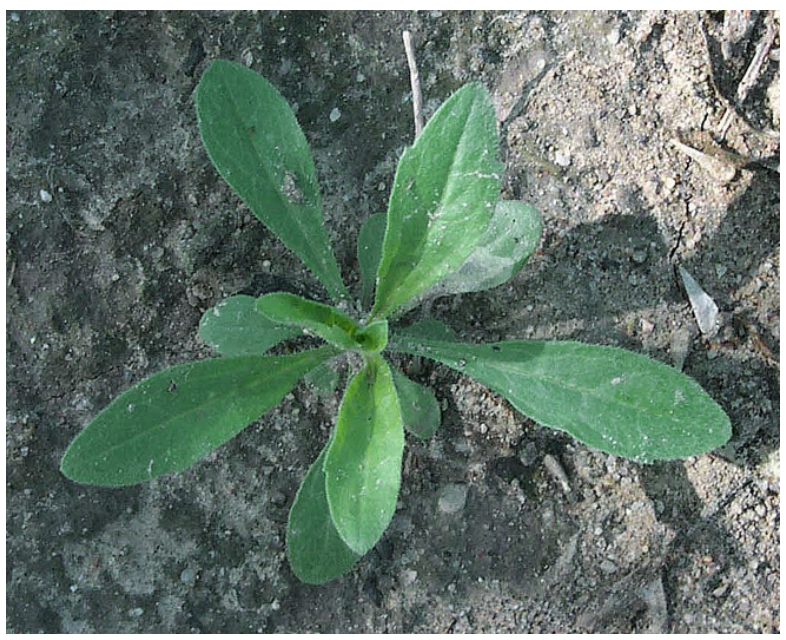

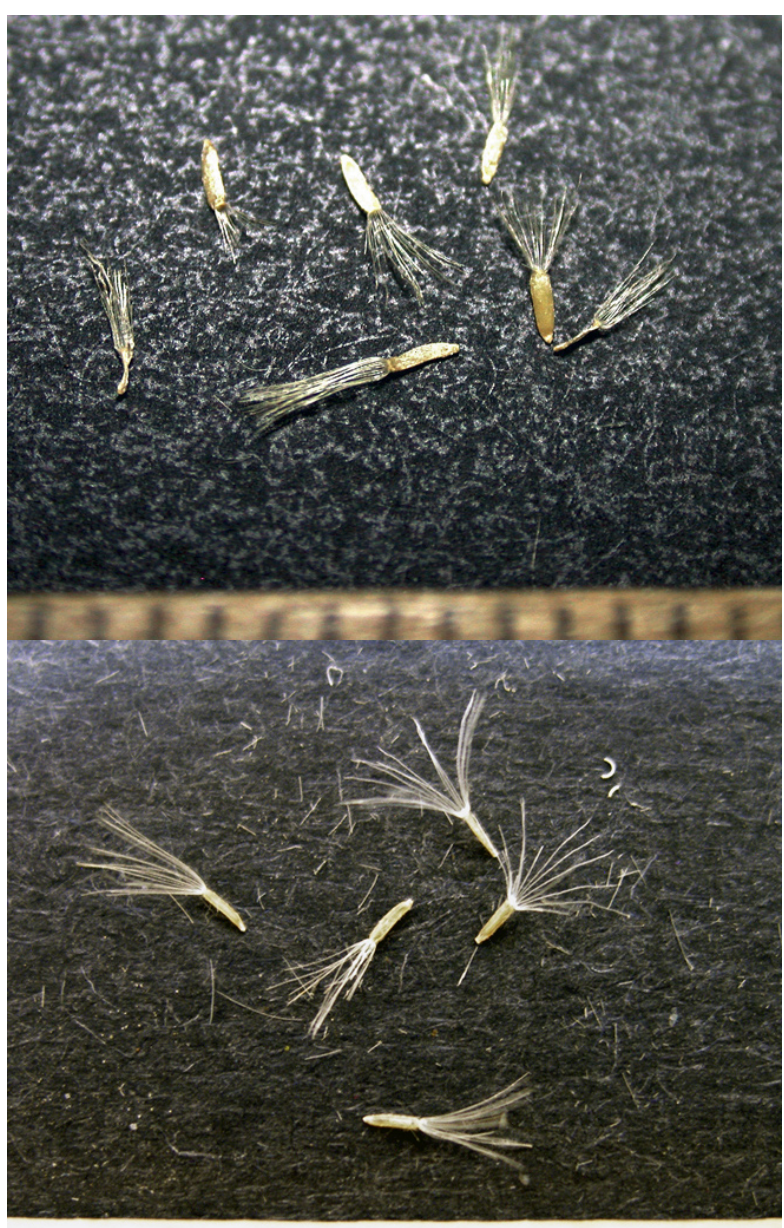

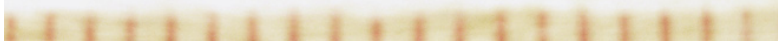

Figure 2. Horseweed (top) and hairy fleabane (bottom) seeds, showing the characteristic pappus that helps in their dissemination. Photos: A. Shrestha.

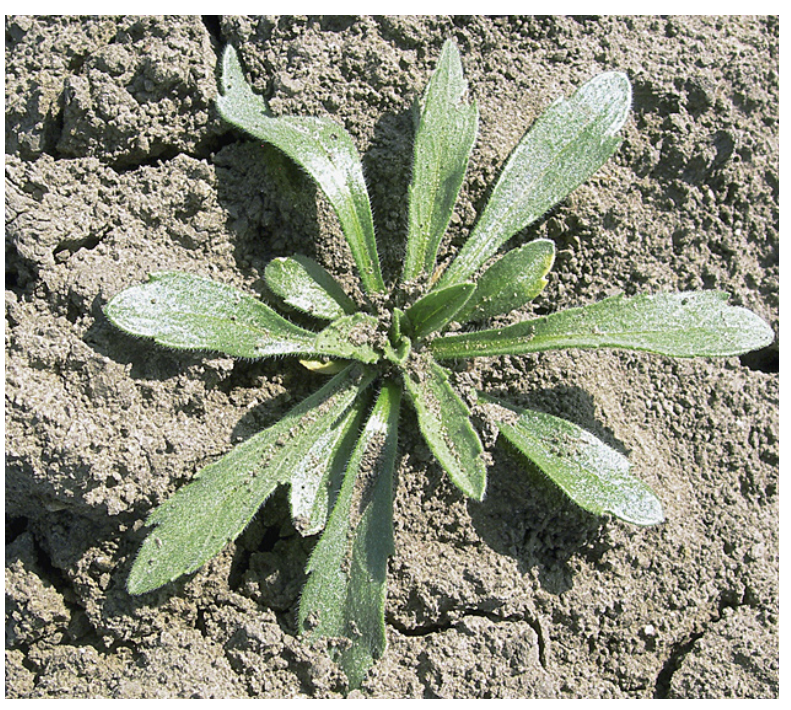

Figure 3. Horseweed seedling (left); hairy fleabane seedling (above). Photos: K. Hembree. 


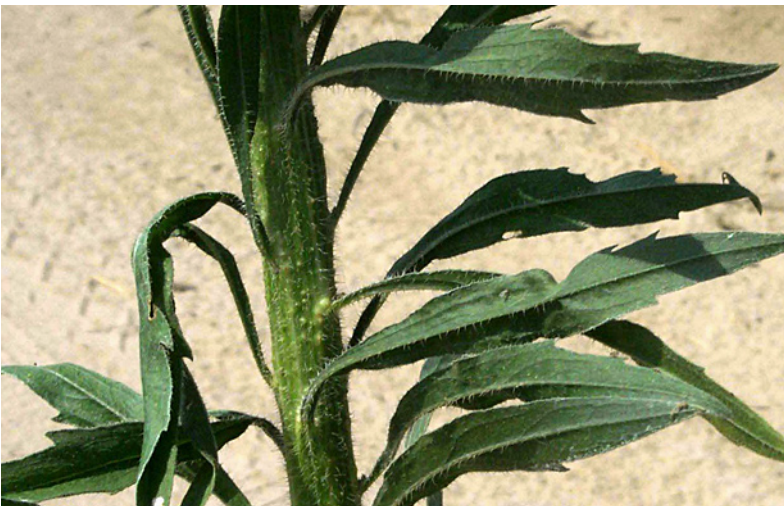

Figure 4. horseweed plant (left) and a hairy fleabane plant (right), showing the arrangement of leaves on the stem. Photos: K. Hembree.

horseweed, develops multiple lateral branching without a central stem and has leaves that are much narrower with stiff hairs. The distance between the leaves is greater in hairy fleabane than in horseweed (see fig. 4). At maturity, horseweed is usually much taller than hairy fleabane. Horseweed can be 10 feet tall, whereas hairy fleabane is usually 1.5 to 3 feet tall (fig. 5).

Both species usually start flowering in July and produce small, yellowish flower heads at the terminal end of branched stems (fig. 6). Occasionally, in Tulare County, hairy fleabane has been observed to flower as early as mid-March. However, the factors responsible for this earliness are not known. Horseweed plants can produce more than 200,000 tiny, narrow (about $1 \mathrm{~mm}$ ) tan-colored seeds (see fig. 2) (Bhowmik and Bekech 1993; Weaver 2001). The plant usually matures and sheds its windblown seeds from late July to October. In some cases, horseweed seeds have been found up to 300 miles away from where they were produced (Shields et al. 2006). Many other growth and habitat characteristics
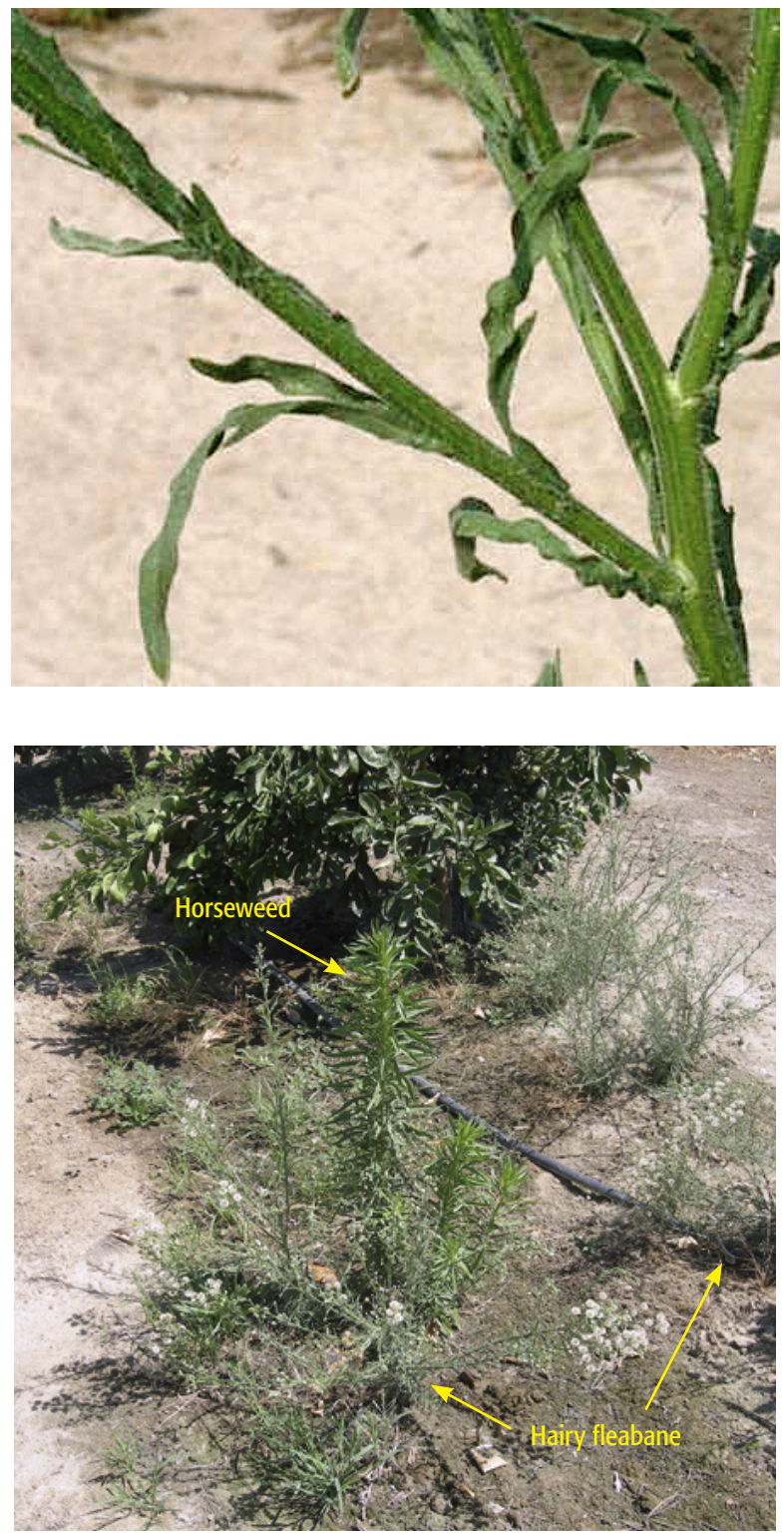

Figure 5. Adult horseweed and hairy fleabane plants in a citrus orchard. Photo: K. Hembree.

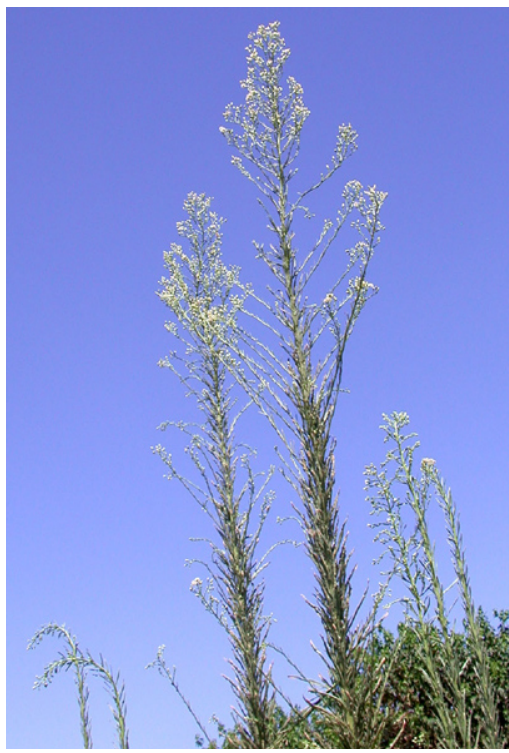

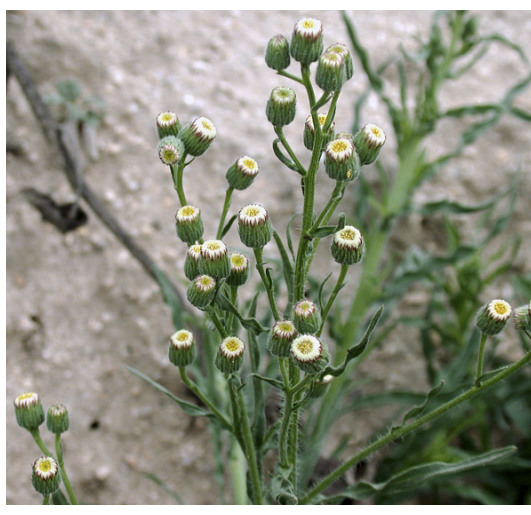

Figure 6B. Inflorescence of hairy fleabane. Photo: A. Shrestha.
Figure 6A. Horseweed inflorescence (left) and an open flower (top). Photos: K. Hembree (I) and A. Shrestha (t). 
of horseweed and hairy fleabane are similar. However, field observations in the Central Valley show that hairy fleabane produces flowers and seeds at least 2 weeks earlier than horseweed.

\section{FIELD ECOLOGY OF HORSEWEED AND HAIRY FLEABANE}

Horseweed and hairy fleabane seem to prefer lesserdisturbed soil environments. In the U.S. Midwest and other parts of the world where growers have converted or are converting to reduced-tillage systems, the prevalence of horseweed and hairy fleabane is increasing (Brown and Whitwell 1988; Weaver 2001). It was found that even minimum tillage (discing) of the soil in spring or fall effectively controlled horseweed (Brown and Whitwell 1988).

This explains why these weeds are observed more in undisturbed situations, such as orchard and vineyard berms, field margins, roadsides, and irrigation or ditch banks in California. In Australia, these species are considered the most difficult weeds to control in no-till systems (Somervaille and McLennan 2003 as cited in Wu et al. 2007).

The longevity of horseweed seeds does not seem to be very long. Seeds stored under dry conditions or in the laboratory had longevity of only 2 to 3 years (Comes et al. 1978; Thébaud et al. 1996). Similarly, the seeds of hairy fleabane survived up to three years under field conditions (Wu et al. 2007). However, a study reported viable seeds of horseweed were found in the seedbank of a 20-year old pasture despite its absence in the vegetation (Weaver 2001). The seeds of these species do not seem to have a dormancy requirement to germinate (Nandula et al. 2006; $\mathrm{Wu}$ et al. 2007). Once the seeds are mature, they germinate as soon as conditions are favorable. This probably explains why recently dispersed seeds of these species emerge where postharvest irrigation water is applied in certain orchards and vineyards.

\section{LOSSES CAUSED BY THESE WEEDS}

Very little data exists on crop yield and quality losses caused by horseweed (see Weaver 2001) and hairy fleabane. In Michigan, it was found that horseweed reduced soybean yields by up to 83 percent (Bruce and Kells 1990). However, horseweed and hairy fleabane can compete directly with young trees and vines for soil nutrients, water, and light. They can reduce tree and vine vigor, especially in newly planted fields. In walnut orchards in California, for example, heavy competition from these weeds can reduce tree height the first year by a foot or more. In cases such as this, growers must either replant or live with a reduced canopy height, which can make it difficult for harvesting equipment to enter the field without injuring low-hanging branches. Horseweed is also known to be a host plant for the glassy-winged sharp shooter (Wistrom and Purcell 2005). These weeds can form dense stands that interfere with the distribution of water, particularly in low-volume sprinkler and drip irrigation systems. These weeds also seem to be an aesthetic nuisance both in agroecosystems and natural or man-made landscapes.

Horseweed can be a major problem in vineyards. If not adequately controlled, horseweed will grow through the vine canopy, interfering with harvest and other field operations (fig. 7). Horseweed may be particularly troublesome for raisin growers who use a continuous tray harvest system. In this system, green grapes are harvested

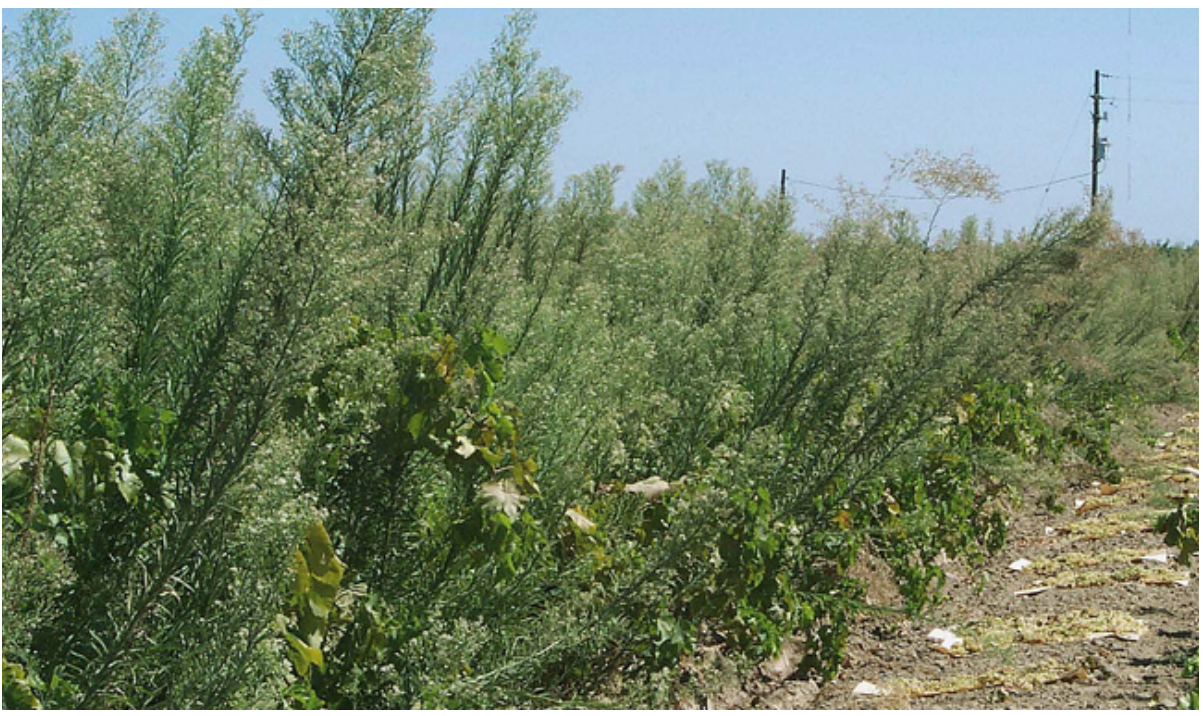

Figure 7.

Horseweed plants towering over a grapevine canopy. Photo: K. Hembree. 
mechanically and are spread on long sheets of paper ("continuous trays") to dry. Invariably, some berries are damaged by the harvester and release juice that can coat the berries and make them sticky. At the same time, horseweed seeds shatter on contact with the harvester, and the dislodged seeds may adhere to the surface of the sticky berries. As the berries dry into raisins, the seeds may be enveloped by the folds of raisin skins.

\section{MANAGEMENT OPTIONS}

Since horseweed and hairy fleabane seeds do not survive for more than a few (approximately 3 ) years under field conditions, controlling plants before they produce new seed is critical for long-term management. Therefore, control tactics should be employed when these weeds are young (seedling to rosette stage) and more sensitive to chemical and nonchemical controls. As these weeds begin to grow upright, their woody stem makes control very difficult and expensive. In home gardens and areas with sandier soils, these weeds can be easily uprooted by hand.

\section{Herbicides}

Preemergent and postemergent herbicides can provide effective control, depending on crop or location used, method of application, rate, application timing, uniformity in soil and weed wetting, and other important factors. Several herbicides used in California are effective on horseweed and hairy fleabane (table 1; also see susceptibility charts in UC IPM Pest Management Guidelines for specific crops). As with all pesticides, follow all label recommendations closely to achieve desired efficacy and crop safety. Since a large complex of weeds is often present at any given time, applying combinations or sequential treatments of different preemergent and postemergent products is usually needed for the best overall control.

For preemergent herbicides to be effective, they need to be applied uniformly to the soil surface before these weeds emerge in late fall through early spring. Control with preemergent herbicides can be reduced if they are applied to soils covered with leaves, weeds, and other debris. Removing debris

Table 1. Herbicides for control of horseweed and hairy fleabane in California

\begin{tabular}{|c|c|c|c|c|c|}
\hline \multicolumn{3}{|c|}{ Preemergent } & \multicolumn{3}{|c|}{ Postemergent } \\
\hline Common name & Trade name & Control rating & Common name & Trade name & Control rating \\
\hline aminopyralid & Milestone & C & aminopyralid & Milestone & C \\
\hline atrazine & AAtrex & C & bromoxynil & Buctril & $\mathrm{P}$ \\
\hline bromacil & Krovar & C & carfentrazone & Shark & $\mathrm{P}$ \\
\hline chlorsulfuron & Glean & C & clopyralid & Transline & $P$ \\
\hline clopyralid & Transline & $\mathrm{P}$ & dicamba & Banvel & C \\
\hline cycloate & Ro-neet & C & diquat & Reglone & C \\
\hline diuron & Karmex & $P$ & glufosinate & Rely & C \\
\hline flumioxazin & Chateau & $P$ & glyphosate & Roundup & $\mathrm{C}^{*}$ \\
\hline halosulfuron & Sandea & $P$ & mсра & MCPA & C \\
\hline hexazinone & Velpar & C & oxyfluorfen & Goal & $P$ \\
\hline isoxaben & Gallery & C & paraquat & Gramoxone & C \\
\hline metam & Vapam & C & pyraflufen & ET, Venue & $P$ \\
\hline norflurazon & Solicam & $P$ & triclopyr & Garlon & C \\
\hline oxyfluorfen & Goal & $P$ & 2,4-D & Dri-Clean & C \\
\hline prometryn & Caparol & C & $2,4-D B$ & Butyrac & C \\
\hline pyrazon & Pyramin & C & & & \\
\hline rimsulfuron & Matrix & C & & & \\
\hline simazine & Princep & C & & & \\
\hline thiazopyr & Visor & $P$ & & & \\
\hline
\end{tabular}

Abbreviations: $\mathrm{C}=$ control; $\mathrm{P}=$ partial control

Notes:

Always read and follow all label recommendations before using any pesticide. Control ratings in this table are based on label recommendations and assume proper application rate and timing. Refer to UC IPM Pest Management Guidelines for information on specific crops. The common names listed may be available under other trade names.

*Except for glyphosate-resistant horseweed and hairy fleabane. 
from the soil surface in an orchard or vineyard before applying preemergent herbicides helps maximize control of horseweed, hairy fleabane, and other weeds. If small weeds are present at the time of application, adding an appropriate postemergent product to the tank can kill those weeds as well. Soil moisture is important for the activation of these herbicides (refer to the herbicide label); timing the application of a preemergent herbicide as close as possible to rainfall or incorporating the herbicide by irrigation is necessary for improved efficacy.

Horseweed and hairy fleabane can also be effectively controlled with postemergent herbicides. However, it is extremely important to treat these weeds when they are very young and to apply the appropriate herbicide label rate. Tank-mixing more than one postemergent product often provides the best overall control, especially if other weeds are present. The most consistent control will be achieved when horseweed and hairy fleabane plants are treated prior to the 14-leaf stage. Once they reach the rosette stage, regrowth often occurs following postemergent treatment. Furthermore, bolted plants have woody stems and form dense canopies, making wetting of the entire plant foliage difficult and reducing the effectiveness of control. In general, applying postemergent herbicides in a spray volume of 30 to 50 gallons per acre provides adequate wetting of the weed foliage necessary for good control. This is especially important where contact-type herbicides (such as glufosinate, paraquat, carfentrazone, etc.) are used. Older and larger horseweed and hairy fleabane plants are more tolerant to systemic herbicides (such as glyphosate), and thus, treating small plants significantly improves control. Repeat applications may be required due to the extended germination period of horseweed and hairy fleabane.

\section{Mechanical Control}

In cases where soil tillage is allowed, control can be achieved without the use of herbicides. Various forms of cultivation are available for both annual and perennial cropping systems. Specialized in-row cultivation equipment such as the hoe plow, in-row roto-tiller, spring hoe weeders, and berm rakes are available for certain orchard and vineyard systems that can provide effective control of these and other seedling weeds. As with herbicides, it is important to use mechanical tools when these weeds are small and most easily controlled.

Mowing is not generally a viable option for control of horseweed and hairy fleabane. Mowing tends to stimulate additional branching from the crown and only delays seed production. Mowing also hardens off these plants, making control with postemergent herbicides nearly impossible. Some success has been achieved with repeated applications of propane flaming, but only with plants at the seedling stage. With current and potential air quality issues in the Central Valley, flaming may not be a practical option in the future.

\section{Biological Control}

Very little information is available on biological control of these two weed species. Since both weeds grow on lesser-disturbed and managed natural ecosystems, their seeds can easily blow into agroecosystems. Therefore, it is important to find methods that prevent the continuous influx of new seeds from the natural ecosystems. The bacterium Pseudomonas syringae pv. tagetis has been reported to affect these weeds (Charudattan 2001), but this has not yet been developed as a large scale biocontrol agent. Similarly, certain stem borers and leaf-eating caterpillars have been observed to damage these plants, but very little information is available on the success of these insects in controlling these weeds.

\section{HERBICIDE RESISTANCE IN HORSEWEED AND HAIRY FLEABANE}

Glyphosate-resistant horseweed was first discovered in Delaware in 2000 (VanGessel 2001). Since then it has spread to 16 states in the United States and has also been reported from Brazil, China, Spain, and the Czech Republic (Heap 2008). Rapid seed dispersal, the expansive use of glyphosate, and the lack of tillage are major factors contributing to the quick invasion of glyphosate-resistant horseweed in the eastern United States (Dauer et al. 2007). In other parts of the United States, glyphosate-resistant horseweed has been reported where glyphosateresistant crops have been used in conjunction with no-till production systems (Dauer et al. 2007; Koger et al. 2004; Nandula et al. 2006). In California, glyphosate-resistant horseweed has been reported in orchards, vineyards, roadsides, and canal banks (Shrestha et al. 2007). Worldwide, including several regions of the United States, horseweed has developed resistance to several different herbicides, such as glyphosate, paraquat, and atrazine (Weaver et al. 2004; Heap 2008). Similarly, glyphosate-resistant hairy fleabane has recently been reported from Spain (Urbano et al. 


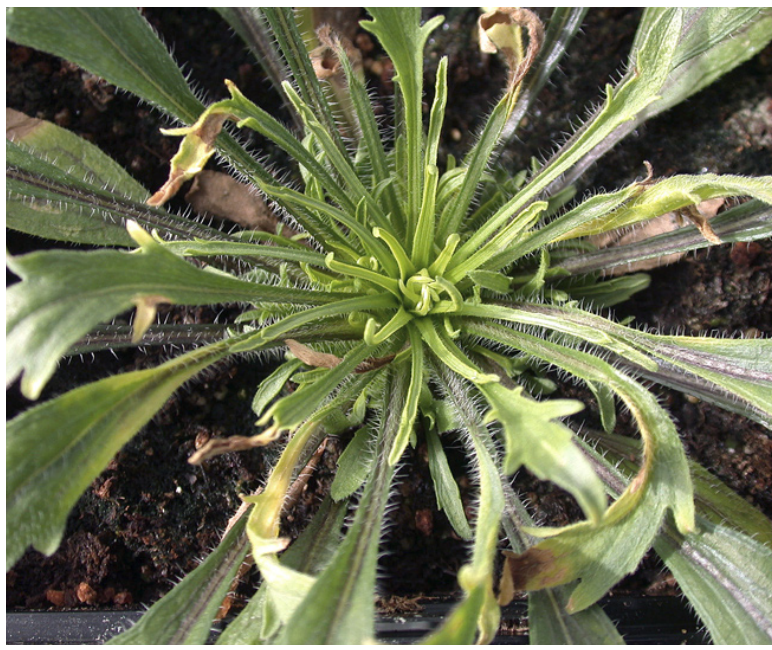

2007) and South Africa (as reported in Heap 2008). Confirmed cases of glyphosate-resistant horseweed (Shrestha et al. 2007) and hairy fleabane (Shrestha et al. 2008) were reported in California in 2005 and 2007, respectively. In California, it was observed that the foliage of horseweed or hairy fleabane would initially show symptoms of injury to glyphosate, but the plants would recover in a few weeks and survive (fig. 8). Even within the same population, portions of the population were controlled while others would survive the glyphosate application (fig. 9). Such observations are characteristic signs of herbicide resistance. Relying on a single herbicide or combination of herbicides year after year increases the likelihood of selection for resistant populations. Rotating other effective products or using tank mixes of products where possible helps prevent or delay herbicide resistance. For detailed information on herbicide resistance management, refer to the Prather et al. 2000.

\section{REFERENCES}

Bhowmik, P. C., and M. M. Bekech. 1993. Horseweed (Conyza canadensis) seed production, emergence, and distribution in no-tillage and conventional-tillage corn (Zea mays). Agron. Trends Agric. Sci. 1:67-71.

Brown S. M., and T. Whitwell. 1988. Influence of tillage on horseweed, Conyza canadensis. Weed Technol. 2:269-270.

Bruce, J. A., and J. J. Kells. 1990. Horseweed (Conyza canadensis) control in no-tillage soybeans (Glycine max) with preplant and preemergence herbicides. Weed Technol. 4:642-647.

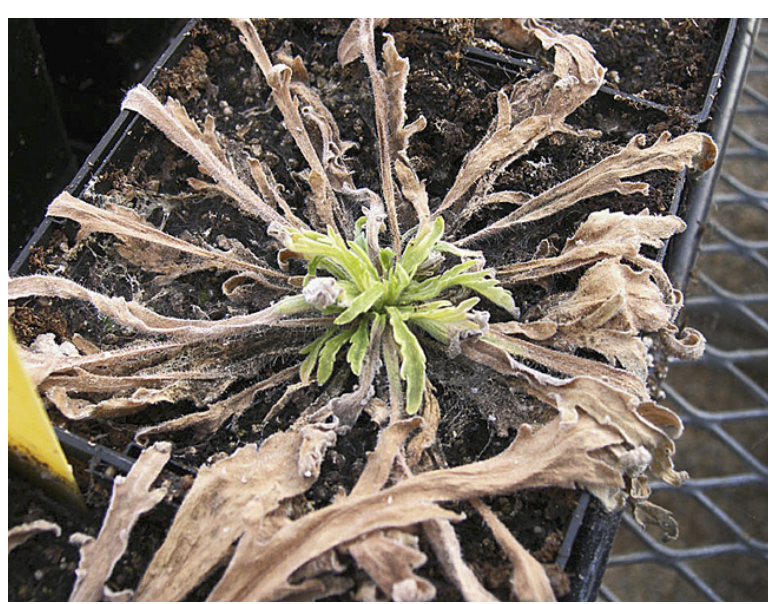

Figure 8. A glyphosate-resistant horseweed (left) and hairy fleabane (right) seedling recovering from herbicide injury. Photos: A. Shrestha.

Buhler, D. D., and M. D. K. Owen. 1997. Emergence and survival of horseweed (Conyza canadensis). Weed Sci. 45:98-101.

Charudattan, R. 2001. Biological control of weeds by means of plant pathogens: Significance for integrated weed management in modern agroecology. BioControl 49:229-260.

Comes, R. D., V. F. Bruns, and A. D. Kelley. 1978. Longevity of certain weed and crop seeds in fresh water. Weed Sci. 26:336-344.

Dauer, J. T., D. A. Mortensen, and M. J. VanGessel. 2007. Temporal and spatial dynamics of long-distance Conyza canadensis seed dispersal. J. Appd. Ecol. 44:105-114.

Heap, I. 2008. International survey of herbicideresistant weeds. WeedScience.org Web site, http://www.weedscience.org.

Karlsson, L. M., and P. Milberg. 2007. Comparing after-ripening response and germination requirements of Conyza canadensis and $C$. bonariensis (Asteraceae) through logistic functions. Weed Res. 47:433-441.

Koger, C. H., D. H. Poston, R. M. Hayes, and R. F. Montgomery. 2004. Glyphosate-resistant horseweed (Conyza canadensis) in Mississippi. Weed Technol. 18:820-825.

Nandula, V. K., T. W. Eubank, D. H. Poston, C. H. Koger, and K. N. Reddy. 2006. factors affecting germination of horseweed (Conyza canadensis). Weed Sci. 54:898-02. 


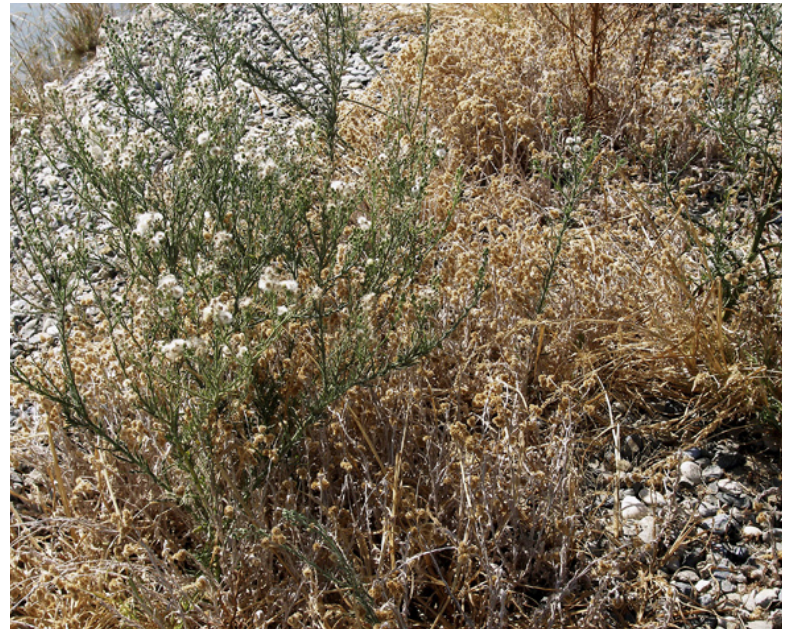

Prather, T. S., J. M. Ditomaso, and J. S. Holt. 2000. Herbicide resistance: Definition and management strategies. Oakland: University of California Agriculture and Natural Resources Publication 8012. UC ANR CS Web site, http:// anrcatalog.ucdavis.edu/Weeds/8012.aspx.

Shields, E. J., J. T. Dauer, M. J. VanGessel, and G. Neumann. 2006. Horseweed (Conyza canadensis) seed collected in the planetary boundary layer. Weed Sci. 54:1063-1067.

Shrestha, A., K. J. Hembree, and N. Va. 2007. Growth stage influences level of resistance in glyphosate-resistant horseweed. Calif. Agric. 61(2): 67-70.

Shrestha, A., B. D. Hanson, and K. J. Hembree. 2008. Glyphosate-resistant hairy fleabane (Conyza bonariensis) documented in the Central valley. Calif. Agric. 62(3): 116-119.

Somervaille, A., and B. McLennan. 2003. The 2nd fallow weed management guide. Toowoomba, Australia: Conservation Farmers.

Thébaud, C., A. C. Finzi, and L. Affre. 1996. Assessing why two introduced Conyza differ in their ability to invade Mediterranean old fields. Ecology 77:791-804.

UC IPM (University of California Statewide Integrated Pest Management Program). Continuously updated. Pest management guidelines. UC IPM Web site, http://www.ipm. ucdavis.edu/PMG/crops-agriculture.html.

Urbano, J. M., A. Borrego, V. Torres, J. M. Leon, C. Jimenez, G. Dinelli, and J. Barnes. 2007. Glyphosate-resistant hairy fleabane (Conyza bonariensis) in Spain. Weed Technol. 29:396-401.

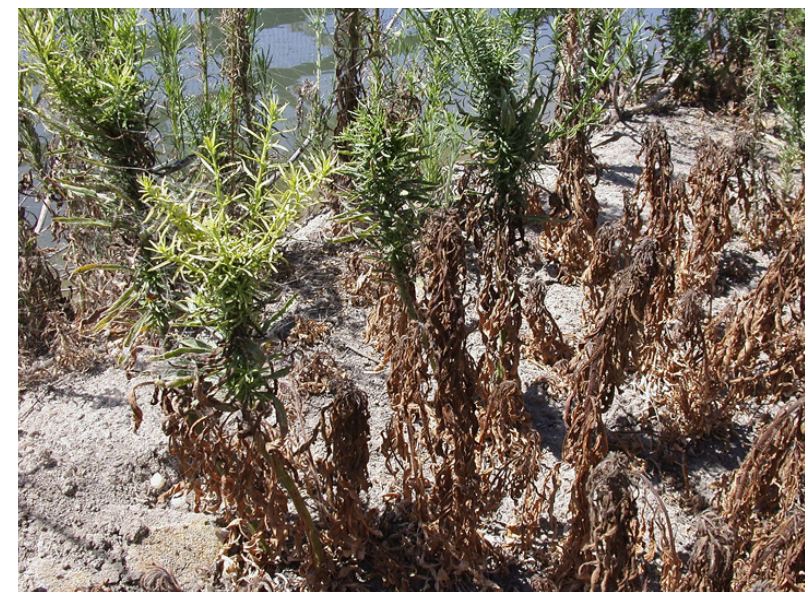

Figure 9. A population of horseweed plants (left) and hairy fleabane (right) showing susceptibility and resistance to glyphosate on a ditch bank. Note the characteristic branching on apex of the surviving horseweed plants on the left. Photos: A. Shrestha.

VanGessel, M. J. 2001. Glyphosate-resistant horseweed from Delaware. Weed Sci. 49:703-705.

Vidal, R. A., A. Kalsing, J. P. Ruiz-Santaella, R. De Prado, and P. J. Christoffoleti. 2007. Conyza bonariensis and Conyza canadensis seed germination as affected by soil depth and composition, light and temperature. Weed Science Society of America Annual Meeting, Feb. 5-9, San Antonio, TX. Abst. \#76.

Weaver, S. E. 2001. The biology of Canadian weeds. 115. Conyza canadensis. Can. J. Plant Sci. 81:867-875.

Weaver, S., M. Downs, and B. Neufeld. 2004. Response of paraquat-resistant and -susceptible horseweed (Conyza canadensis) to diquat, linuron, and oxyfluorfen. Weed Sci. 52:549-553.

Wistrom, C., and A. H. Purcell. 2005. The fate of Xylella fastidiosa in vineyard weeds and other alternate hosts in California. Plant Dis. 84:994-999.

Wu, H., S. Walker, M. J. Rollin, D. K. Y. Tan, G. Robinson, and J. Werth. 2007. Germination, persistence, and emergence of flaxleaf fleabane (Conyza bonariensis [L.] Cronquist). Weed Biol. Mgmt. 7:192-199.

Zinzolker, A., J. Kigel, and B. Rubin. 1985. Effects of environmental factors on the germination and flowering of Conyza albida, C. bonariensis and C. canadensis. Phytoparasitica 13:229-230. 


\section{English-Metric Conversions}

\begin{tabular}{|l|l|l|l|}
\hline English & $\begin{array}{l}\text { Conversion factor for } \\
\text { English to metric }\end{array}$ & $\begin{array}{l}\text { Conversion factor for } \\
\text { metric to English }\end{array}$ & Metric \\
\hline inch (in) & 2.54 & 0.394 & centimeter $(\mathrm{cm})$ \\
\hline foot $(\mathrm{ft})$ & 0.3048 & 3.28 & meter $(\mathrm{m})$ \\
\hline gallon per acre $(\mathrm{gpa})$ & 9.36 & 0.106 & liter per hectare $(\mathrm{l} / \mathrm{ha})$ \\
\hline Fahrenheit $\left({ }^{\circ} \mathrm{F}\right)$ & ${ }^{\circ} \mathrm{C}=\left({ }^{\circ} \mathrm{F}-32\right) \div 1.8$ & ${ }^{\circ} \mathrm{F}=\left({ }^{\circ} \mathrm{C} \times 1.8\right)+32$ & Celsius $\left({ }^{\circ} \mathrm{C}\right)$ \\
\hline
\end{tabular}

\section{FOR FURTHER INFORMATION}

To order or obtain printed publications and other products, visit the ANR Communication Services online catalog at http://anrcatalog.ucdavis.edu. You can also place orders by mail, phone, or FAX, or request a printed catalog of our products from:

\section{University of California}

Agriculture and Natural Resources

Communication Services

6701 San Pablo Avenue, 2nd Floor

Oakland, California 94608-1239

Telephone: (800) 994-8849 or (510) 642-2431

FAX: (510) 643-5470

E-mail inquiries: danrcs@ucdavis.edu

(C2008 The Regents of the University of California

Agriculture and Natural Resources

All rights reserved.

No part of this publication may be reproduced, stored in a retrieval system, or transmitted, in any form or by any means, electronic, mechanical, photocopying, recording, or otherwise, without the written permission of the publisher and the authors.

\section{Publication 8314}

ISBN-13: 978-1-60107-572-7

The University of California prohibits discrimination or harassment of any person on the basis of race, color, national origin, religion, sex, gender identity, pregnancy (including childbirth, and medical conditions related to pregnancy or childbirth), physical or mental disability, medical condition (cancer-related or genetic characteristics), ancestry, marital status, age, sexual orientation, citizenship, or service in the uniformed services (as defined by the Uniformed Services Employment and Reemployment Rights Act of 1994: service in the uniformed services includes membership, application for membership, performance of service, application for service, or obligation for service in the uniformed services) in any of its programs or activities.
University policy also prohibits reprisal or retaliation against any person in any of its programs or activities for making a complaint of discrimination or sexual harassment or for using or participating in the investigation or resolution process of any such complaint.

University policy is intended to be consistent with the provisions of applicable State and Federal laws.

Inquiries regarding the University's nondiscrimination policies may be directed to the Affirmative Action/Equal Opportunity Director, University of California, Agriculture and Natural Resources, 1111 Franklin Street, $6^{\text {th }}$ Floor, Oakland, CA 94607, (510) 987-0096. For information about ordering this publication, telephone 1-800-994-8849. For assistance in downloading this publication, telephone 530-754-3927.

An electronic copy of this publication can be found at the ANR Communication Services catalog Web site, http://anrcatalog.ucdavis.edu.

To simplify information, trade names of products have been used. No endorsement of named or illustrated products is intended, nor is criticism implied of similar products that are not mentioned or illustrated.

\section{UCCY}

REVIEWED This publication has been anonymously peer reviewed for technical accuracy by University of California scientists and other qualified professionals. This review process was managed by the ANR Associate Editor for Agricultural Pest Management.

pr-10/08-SB/CR 